\title{
Reliability and safety of a new upper cervical spine injury treatment algorithm
}

\author{
Avaliação de reprodutibilidade e segurança de um novo algoritmo de tratamento das \\ lesões cervicais altas
}

\author{
Andrei Fernandes Joaquim 1,2, Roger Schmidt Brock1, Vinicius Monteiro de Paula Guirado', Luis Henrique Sandon', \\ Otávio Turolo da Silva², Mário Augusto Taricco', Manoel Jacobsen Teixeira', Eberval Gadelha Figueiredo'
}

\begin{abstract}
In the present study, we evaluated the reliability and safety of a new upper cervical spine injury treatment algorithm to help in the selection of the best treatment modality for these injuries. Methods: Thirty cases, previously treated according to the new algorithm, were presented to four spine surgeons who were questioned about their personal suggestion for treatment, and the treatment suggested according to the application of the algorithm. After four weeks, the same questions were asked again to evaluate reliability (intra- and inter-observer) using the Kappa index. Results: The reliability of the treatment suggested by applying the algorithm was superior to the reliability of the surgeons' personal suggestion for treatment. When applying the upper cervical spine injury treatment algorithm, an agreement with the treatment actually performed was obtained in more than $89 \%$ of the cases. Conclusion: The system is safe and reliable for treating traumatic upper cervical spine injuries. The algorithm can be used to help surgeons in the decision between conservative versus surgical treatment of these injuries.
\end{abstract}

Keywords: spinal injuries; spinal cord injuries; therapeutics; classification.

\section{RESUMO}

Avaliamos a reprodutibilidade e segurança do algoritmo Upper Cervical Spine Injuries Treatment Algorithm (UCITA) recém proposto para a escolha do tratamento das lesões traumáticas da junção crânio-cervical. Métodos: Trinta casos previamente tratados de acordo com o algoritmo foram apresentados a quatro cirurgiões de coluna, sendo questionada a conduta pessoal dos mesmos e a conduta segundo a aplicação do algoritmo. Após 4 semanas, foram refeitas as mesmas perguntas para avaliar a reprodutibilidade (intra e interobservador) do algoritmo, através do índice estatístico "Kappa". Resultados: A reprodutibilidade da conduta com o uso do algoritmo foi superior a reprodutibilidade da conduta pessoal dos cirurgiões. Com o uso do UCITA, a concordância do tratamento realmente efetivado foi encontrada em mais de $89 \%$ dos casos. Conclusão: 0 uso do UCITA foi seguro e reprodutível, podendo ser usado como ferramenta auxiliar na tomada de decisão entre tratamento cirúrgico versus conservador dos traumatismos da junção crâniocervical.

Palavras-chave: traumatismos da coluna vertebral; traumatismos da medula espinal; terapêutica; classificação.

Upper cervical spine injuries are the most severe traumatic lesions that affect the spine, and are potentially associated with tetraplegia, respiratory dysfunction and even sudden death ${ }^{1,2,3,4}$. These include injuries that may affect the occipital condyles, the atlas and the axis, as well as their adjacent ligamentous and facet joints. The stability of most of this region relies on powerful and complex ligamentous support, which allows the majority of cervical rotation (especially in the atlanto-axial joints) and flexion-extension (especially between the occipital condyles and the lateral masses of the atlas $)^{5,6}$.

Treatment goals are relatively well established and include: 1) maintenance or restoration of spinal stability, 2) protection and/or decompression of the spinal cord,3) correction or avoidance of progressive spinal deformities. In the last few years, many new surgical techniques and spinal instrumentation systems have been developed, providing immediate stability with selective fusion of the involved levels ${ }^{3,7,8}$.

However, due to the complexity of its anatomy and a multitude of possible injury patterns that affects this region, many classification schemes have been proposed for upper cervical spine injuries in the past decades, precluding an objective and standardized treatment. This context may result in heterogeneous treatment and complex classifications, sometimes not easily applied in the decision-making process of

1 Universidade de São Paulo, Divisão de Neurocirurgia, São Paulo SP, Brasil;

${ }^{2}$ Universidade Estadual de Campinas, Divisão de Neurocirurgia, Campinas SP, Brasil.

Correspondence: Andrei F. Joaquim; Divisão de Neurocirurgia, UNICAMP; Rua Tessália Vieira de Camargo, 126; 13083-872 Campinas SP, Brasil;

E-mail: andjoaquim@yahoo.com

Conflict of interest: There is no conflict of interest to declare.

Received 22 September 2016; Received in final form 09 November 2016; Accepted 09 November 2016. 
conservative versus surgical treatment ${ }^{9}$. Among numerous schemes some deserve attention, such as the Anderson and D’Alonzo classification, published in 1974, for odontoid fractures, the Effendi et al. ${ }^{2}$ and the Levine and Edwards classification for injuries of the posterior elements of the axis, the Anderson and Montesano classification for occipital condyle fractures, among many others ${ }^{1,4,10}$. Most of them are complex, which may result in different classifications for the same specific injury pattern, as well as different treatment modalities. Also important is that the majority of these systems were proposed in the era of plain radiographs, without the details of recent 3D CT reconstructions that may display these injuries with higher sensitivity and specificity. In some cases, where soft tissue injuries cannot clearly be identified using CT imaging, an MRI provides additional information about the spinal cord and nerve roots, even though this information is not included in the vast majority of the classical classification systems ${ }^{3,9}$.

In this scenario, a unified and simplified classification system for upper cervical spine injuries became necessary. In 2014, Joaquim et al. ${ }^{9}$ proposed a new upper cervical spine injury treatment algorithm for choosing between conservative and surgical treatment for upper cervical spine injuries, based on a literature review of the accepted surgical indications for traumatic injuries of the upper cervical spine and craniovertebral junction. The idea of this new system is to classify injuries according to: 1) integrity of their ligamentous injuries - disrupted ligaments (with or without fractures) may preferentially be treated with surgical fixation due to their high risk of instability and neurological deterioration; and 2) isolated fractures, which should be managed conservatively, with surgery reserved for those who have had a high rate of nonhealing or failure of conservative treatment (with deformity, misalignment or neurological risk). An adapted version of the algorithm is presented in the Figure.

However, although promising, this proposed algorithm requires further validation. The main goals of this study were to evaluate the reproducibility and the safety of this new algorithm in supporting surgeons to choose between conservative versus surgical treatment of upper cervical spine injuries.

\section{METHODS}

Thirty cases, previously treated according to the new algorithm, were presented to four spine surgeons. Of the 30 cases included in our study, 19 were treated conservatively, achieving good bone healing and also maintaining normal cervical alignment, whereas 11 were referred for surgical fixation according to the upper cervical spine injury treatment

\section{Traumatic Upper Cervical Injuries}

Evaluate if there is a ligamentous Injury:

1) abnormal misalignment, outside the normative ranges of alignment, 2) perched or locked facet joints, 3) increase atlanto-dens interval $>3.5 \mathrm{~mm}$

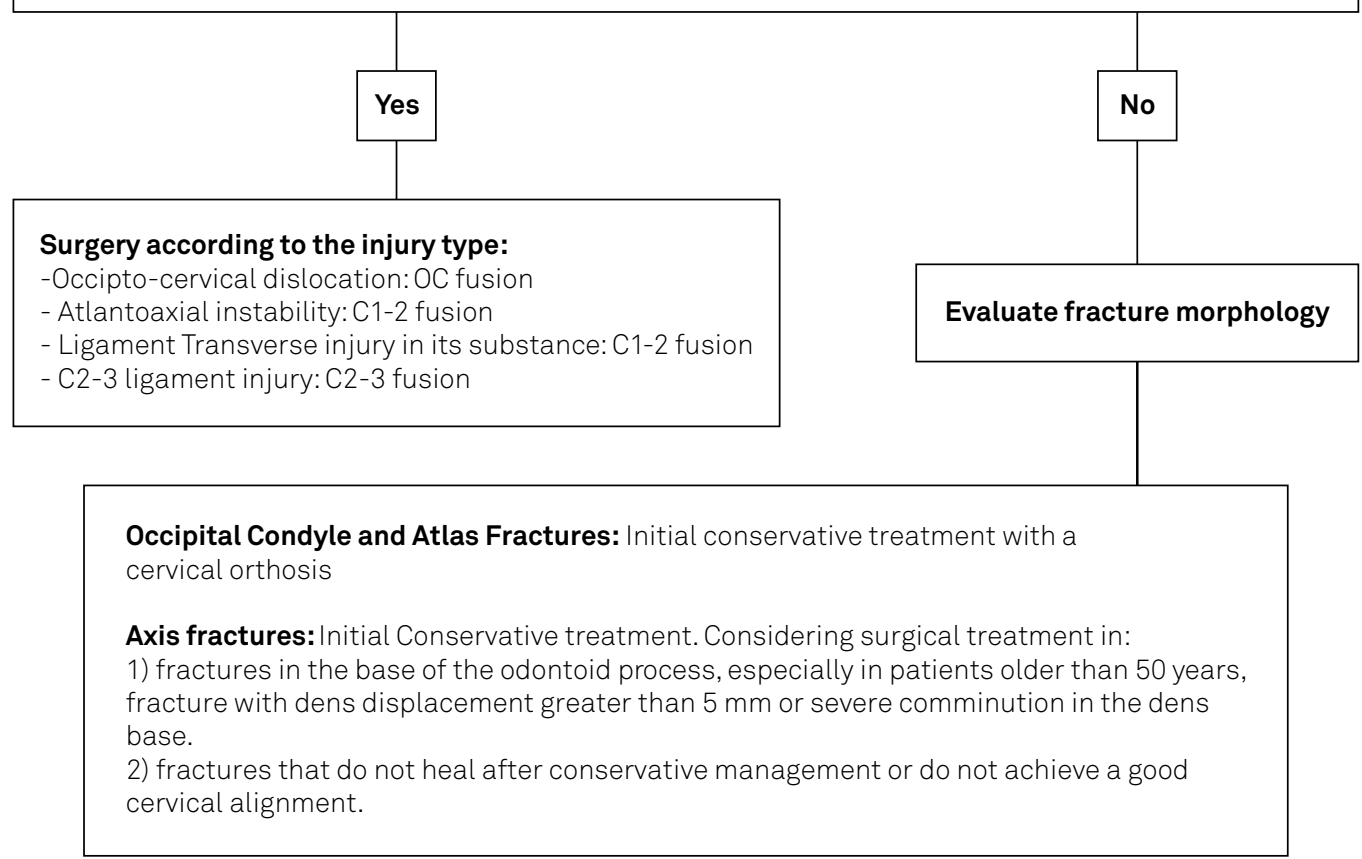

OCD: Occipto-cervical dislocation; OC: Occipto-cervical; AA: Atlanto-axial Instabilit; LT: Transverse Ligament.

Figure. Adapted algorithm from Joaquim et al. ${ }^{9}$, for treatment of upper cervical spine injuries. 
algorithm applied by one of the authors. There were 23 men $(76.7 \%)$ and seven women $(23.3 \%)$ in this series. Ages ranged from 16 to 77 years (mean 38.4, median 37, SD \pm 14.41 years). The mean follow up was 13.5 months (ranging from three to 36 months, with a median of $10.5, \mathrm{SD} \pm 11.2$ months). The mean follow up was 21 months in the surgical group compared with 9.1 months in the group managed conservatively.

After institutional review board approval (CAAE: 53542416.2.0000.0065), the algorithm description was presented by one of the authors to four spine surgeons with expertise in the management of spinal cord injuries. All four evaluators were board-certified neurosurgeons. After that, 30 consecutive cases (> 16 years old) of upper cervical spine injuries, treated by one of the authors, were presented digitally with high resolution images, with age and neurological status (assessed on the American Spine Injury Association Impairment Scale - AIS), to the four surgeons (RSB, VMPG, LHS, MAT). These patients had been treated according to the algorithm and the treatment was blinded to the four evaluators. All the patients were followed up after hospital discharge by the same surgeon (AFJ) with routine radiological and clinical follow up (two weeks, one month, three months and then every six months after hospital discharge, with dynamic plain radiographs and CT scans when necessary). A successful conservative treatment was considered when there was evident bone healing and a good cervical alignment on post-injury images at least three months after the trauma, without incapacitating local pain.

The evaluators were questioned about: 1) the specific diagnosis of the upper cervical spine injury (injury classification according to the evaluator's preference), 2) their personal treatment proposal (conservative versus surgical), based on their own clinical experience, and 3) management option according to the application of the algorithm, with a total of three answers for each patient. After four weeks, the same questions were presented again. Both intra- and inter-observer agreements were assessed using the kappa coefficient (Table 1), calculated with the STATA software for Windows, version 13.

In order to evaluate safety, we compared the actual treatment for the 30 patients with the treatment proposed by the each of the evaluators.

\section{RESULTS}

\section{General results}

The mechanisms of the injuries were as a result of 24 patients $(80 \%)$ being involved in motor vehicle accidents, five $(16.7 \%)$ falling from a height and one diving into shallow water $(3.3 \%)$. One patient, with an odontoid fracture in the dens base, without risk factors for nonunion, was initially conservatively managed, but then required late surgery for nonhealing (three months) and mild persistent cervical pain and was, therefore, included in the surgical group. In 19 patients treated conservatively, all were AIS E at the index level (except for one patient with a concomitant thoracic fracture and AIS A at T3). Of the 11 patients who underwent surgical treatment, seven were AIS E and four were AIS C by the time surgical treatment was indicated. Posterior atlanto-axial fusion was performed in seven patients, two patients had an occipito-C2-3 fusion, one had an anterior C2-3 fixation and fusion and one had a C1-2-3 instrumented fusion. The clinical data of all patients included in this study are summarized in Table 2 (conservative treatment) and Table 3 (surgical treatment). No patient had additional surgery for local pain or severe disability during the follow up.

\section{Classification systems used for the evaluators to guide treatment of upper cervical spine injuries}

To describe injury characteristics in the first and in the second evaluation, the evaluators used a total of ten classifications systems/eponyms for upper cervical spine injuries, as shown in Table 4.

\section{Evaluation of reliability}

\section{Intra-observer analysis}

Table 5 shows the results of intra-observer reliability assessed for treatment proposal in each round, and suggested treatment according to the algorithm.

Table 6 shows the results of intra-observer reliability assessed for treatment according to the application of the algorithm, and the treatment actually performed.

\section{Inter-observer analysis}

Table 7 shows the inter-observer reliability, assessed for personal treatment option and for the treatment proposed by the application of the algorithm.

\section{Validity}

Table 8 shows the agreement rates according to three variables: 1) treatment proposal by the evaluator and the application of the algorithm, 2) application of the algorithm and treatment actually performed and 3) treatment proposal by the evaluator and the treatment actually performed.

Of the 34 answers where there was disagreement between the treatment suggestion by the evaluator and the application of the algorithm, 20 (58.8\%) occurred in odontoid fractures, attesting to the controversies in the management of these injuries.

Table 1. Kappa values according the Landis and Koch grading system ${ }^{15}$

\begin{tabular}{lc}
\hline K value & Agreement \\
\hline$<0.20$ & Slight \\
$0.21-0.40$ & Fair \\
$0.41-0.60$ & Moderate \\
$0.61-0.80$ & Substantial \\
$0.81-1.00$ & Excellent \\
\hline
\end{tabular}


Table 2. Summary of 19 patients treated conservatively.

\begin{tabular}{|c|c|c|c|c|}
\hline Case & Age & Injury description & Etiology & AIS - Observations \\
\hline 1 & 21 & Linear fracture of $\mathrm{C} 2$ body & Dive in shallow water & AISE \\
\hline 2 & 58 & Fracture of the anterior arch of $\mathrm{C} 1$ and also a linear fracture of $\mathrm{C} 2$ body & MVA & AISE \\
\hline 3 & 28 & Linear fracture of the posterior elements of $\mathrm{C} 2$ without displacement & MVA & AIS E \\
\hline 4 & 33 & Linear fracture of the posterior elements of $\mathrm{C} 2$ & MVA & $\begin{array}{c}\text { AIS E } \\
\text { AIS A - thoracic level } \\
\text { (T3 fracture) }\end{array}$ \\
\hline 5 & 38 & Fracture of the dens base without displacement & MVA & AIS E \\
\hline 6 & 60 & Fracture of the body of $\mathrm{C} 2$ & Fall from a height & AIS E \\
\hline 7 & 38 & Fracture of the body of $\mathrm{C} 2$ & MVA & AIS E \\
\hline 8 & 38 & Fracture of the dens base & MVA & AISE \\
\hline 9 & 26 & Linear right side condyle fracture & MVA & AIS E \\
\hline 10 & 37 & Fracture of both anterior and posterior arches of $\mathrm{C} 1$ & MVA & AISE \\
\hline 11 & 44 & Linear fracture of the posterior elements of $\mathrm{C} 2$ & MVA & AIS E \\
\hline 12 & 17 & Fracture of the body of $\mathrm{C} 2$ & MVA & AIS E \\
\hline 13 & 35 & Fracture of the anterior arch of $\mathrm{C} 1$ & Fall from the height & AISE \\
\hline 14 & 43 & Linear fracture of the body of $\mathrm{C} 2$ & MVA & AISE \\
\hline 15 & 36 & $\begin{array}{c}\text { Fracture of the posterior elements of } \mathrm{C} 2 \text { and mild increase } \\
\text { of the angulation of } \mathrm{C} 2 \text { over } \mathrm{C} 3\end{array}$ & MVA & AISE \\
\hline 16 & 43 & $\begin{array}{c}\text { Fracture of the body of } \mathrm{C} 2 \text { involving the left } \mathrm{C} 12 \text { joint but without any } \\
\text { displacement }\end{array}$ & MVA & AIS E \\
\hline 17 & 48 & $\begin{array}{l}\text { Linear left side occipital condyle fracture without displacement of the } \\
\text { facet joints }\end{array}$ & MVA & AIS E \\
\hline 18 & 59 & Linear fracture of the posterior arch of $\mathrm{C} 1$ without displacement & MVA & AISE \\
\hline 19 & 45 & Linear fracture of the posterior elements of $\mathrm{C} 2$ without displacement & MVA & AISE \\
\hline
\end{tabular}

AIS: American Spine Injury Association Impairment Scale, MVA: motor vehicle accidents.

Table 3. Summary of 11 patients operated on.

\begin{tabular}{|c|c|c|c|c|}
\hline Case & Age & Injury Description & Etiology & AIS - Observations \\
\hline 1 & 35 & Fracture of the dens base & MVA & $\begin{array}{c}\text { AIS E } \\
\text { Posterior C12 fixation } \\
\text { Heavy smoker } \\
\text { Failure of conservative treatment due to } \\
\text { pseudoarthrosis }\end{array}$ \\
\hline 2 & 60 & Fracture of the dens base & MVA & $\begin{array}{c}\text { AIS E } \\
\text { Posterior C12 fixation }\end{array}$ \\
\hline 3 & 45 & $\begin{array}{l}\text { Fracture of the posterior elements of C2 with unilateral } \\
\text { subluxation } \mathrm{C} 23\end{array}$ & Fall from the roof & $\begin{array}{c}\text { AIS E } \\
\text { Anterior C23 fixation }\end{array}$ \\
\hline 4 & 16 & Fracture of the odontoid and $\mathrm{C} 12$ luxation & MVA & $\begin{array}{c}\text { AIS C } \\
\text { Posterior C12 fixation }\end{array}$ \\
\hline 5 & 31 & $\begin{array}{l}\text { Fracture of the base of the dens with dens luxation } \\
\text { anteriorly }\end{array}$ & MVA & $\begin{array}{c}\text { AIS E } \\
\text { Posterior C12 fixation } \\
\text { Wound infection requiring antibiotics }\end{array}$ \\
\hline 6 & 37 & $\begin{array}{l}\text { Fracture of } \mathrm{C} 1 \text { and } \mathrm{C} 2 \text { and } \mathrm{C} 12 \text { subluxation } \\
\qquad \mathrm{C} 2 \text { fracture in the dens base }\end{array}$ & MVA & $\begin{array}{c}\text { AISE } \\
\text { Posterior C123 fixation } \\
\text { AISE }\end{array}$ \\
\hline 7 & 37 & $\begin{array}{l}\text { Fracture of C1 lateral mass and unilateral subluxation of } \\
\qquad \text { C12 and condyle-C1 }\end{array}$ & MVA & $\begin{array}{c}\text { AIS E } \\
\text { Occipito-C23 Fixation }\end{array}$ \\
\hline 8 & 16 & C12 luxation and fracture of the dens base & MVA & $\begin{array}{c}\text { AIS C } \\
\text { Last follow up AIS E } \\
\text { Posterior C12 fixation }\end{array}$ \\
\hline 9 & 77 & Fracture of the dens with its displacement posteriorly & Fall from a height & $\begin{array}{c}\text { AIS E } \\
\text { Posterior C12 fixation }\end{array}$ \\
\hline 10 & 20 & Occipital C1-2 distraction & MVA & $\begin{array}{c}\text { AIS C } \\
\text { Last follow up AIS D } \\
\text { Posterior occipital C23 fixation }\end{array}$ \\
\hline 11 & 31 & C12 luxation & Fall from a height & $\begin{array}{c}\text { AIS C } \\
\text { Last follow up AIS D } \\
\text { Posterior C12 fixation }\end{array}$ \\
\hline
\end{tabular}

AIS: American Spine Injury Association Impairment Scale, MVA: motor vehicle accidents. 
Table 4. Most-used systems for treatment of upper cervical spine injuries (note: some injuries were classified more than once).

\begin{tabular}{|c|c|c|c|}
\hline Classification & $\mathrm{N}$ (first evaluation) & $\mathrm{N}$ (second evaluation) & Total \\
\hline Anderson and D'Alonzo' (for fractures of the axis) & 45 & 41 & 86 \\
\hline Primary injury description & 27 & 36 & 63 \\
\hline Levine and Edwards ${ }^{11}$ (for posterior elements of the axis fractures) & 16 & 17 & 33 \\
\hline Benzel et al..$^{16}$ (for axis body fractures) & 8 & 8 & 16 \\
\hline Grauer et al..$^{14}$ (for odontoid fractures) & 7 & 9 & 16 \\
\hline Fujimura et al..$^{17}$ (for axis body fractures) & 6 & 8 & 14 \\
\hline Anderson and Montesano ${ }^{10}$ (for occipital condyle injuries) & 5 & 1 & 6 \\
\hline "Jefferson" fracture ${ }^{12,13}$ (for atlas injuries) & 4 & 4 & 8 \\
\hline Fielding and Hawkings classification ${ }^{18}$ (for atlanto-axial instability) & 4 & 4 & 8 \\
\hline Tuli et al..$^{19}$ (for occipital condyles) & 4 & 3 & 7 \\
\hline "Hangman's fractures"11 (for posterior elements of C2) & 3 & 0 & 3 \\
\hline
\end{tabular}

Table 5. Intra-observer reliability assessment of each evaluator according to personal treatment proposal and the treatment suggested by the algorithm.

\begin{tabular}{lcc}
\hline Evaluator & Kappa - first evaluation & Kappa - second evaluation \\
\hline $1^{\text {st }}$ & 0.4828 (Moderate) & 0.6667 (Substantial) \\
$2^{\text {nd }}$ & 0.7964 (Substantial) & 0.6637 (Substantial) \\
$3^{\text {rd }}$ & 0.9333 (Excellent) & 0.7183 (Substantial) \\
$4^{\text {th }}$ & 0.7945 (Substantial) & 0.6666 (Substantial) \\
\hline
\end{tabular}

Table 6. Intra-observer reliability assessment of each evaluator according to treatment proposed by the application of the algorithm and the treatment actually performed

\begin{tabular}{lcc}
\hline Evaluator & Kappa - first evaluation & Kappa - second evaluation \\
\hline $1^{\text {st }}$ & 0.6193 (Substantial) & 0.6479 (Substantial) \\
$2^{\text {nd }}$ & 0.8565 (Excellent) & 0.7235 (Substantial) \\
$3^{\text {rd }}$ & 0.7964 (Substantial) & 0.8507 (Excellent) \\
$4^{\text {th }}$ & 0.9296 (Excellent) & 0.7333 (Substantial) \\
\hline
\end{tabular}

Table 7. Reliability assessment of treatment proposal by the evaluator and the treatment proposed by the application of the algorithm.

\begin{tabular}{lcc}
\hline Evaluation & Kappa - personal treatment proposal & Kappa - treatment proposed by the algorithm \\
\hline $1^{\text {st }}$ & 0.5996 (Moderate) & 0.6326 (Substantial) \\
$2^{\text {nd }}$ & 0.4661 (Moderate) & 0.5378 (Moderate) \\
$1^{\text {st }}$ and $2^{\text {nd }}$ rounds together & 0.5662 (Moderate) & 0.6292 (Substantial) \\
\hline
\end{tabular}

Table 8. Evaluation of the agreement rates according to three variables: 1) treatment proposal by the evaluator and the application of the algorithm, 2) application of the algorithm and treatment actually performed and 3) treatment proposal by the evaluator and the treatment actually performed.

\begin{tabular}{|c|c|c|c|}
\hline Evaluator & $\begin{array}{l}\text { Agreement of treatment proposal } \\
\text { by the evaluator and the } \\
\text { application of the algorithm }\end{array}$ & $\begin{array}{l}\text { Application of the algorithm and } \\
\text { treatment performed }\end{array}$ & $\begin{array}{l}\text { Treatment proposal by the evaluator } \\
\text { and treatment performed }\end{array}$ \\
\hline \multicolumn{4}{|l|}{$1^{\text {st }}$ Round } \\
\hline $1^{\text {st }}$ & $22 / 30(73.33 \%)$ & $26 / 30(86.67 \%)$ & $23 / 30(76.67 \%)$ \\
\hline $2^{\text {nd }}$ & $27 / 30(90 \%)$ & $27 / 30(90 \%)$ & $27 / 30(90 \%)$ \\
\hline $3^{\text {rd }}$ & $27 / 30(90 \%)$ & $29 / 30(96.67 \%)$ & $28 / 30(93.33 \%)$ \\
\hline $4^{\text {th }}$ & 29/30 (96.67\%) & $27 / 30(90 \%)$ & $26 / 30(86.67 \%)$ \\
\hline \multicolumn{4}{|l|}{$2^{\text {nd }}$ Round } \\
\hline $1^{\text {st }}$ & $25 / 30(83.33 \%)$ & $25 / 30(83.33 \%)$ & $24 / 30(80 \%)$ \\
\hline $2^{\text {nd }}$ & $25 / 30(83.33 \%)$ & $26 / 30(86.67 \%)$ & $25 / 30(83.33 \%)$ \\
\hline $3^{\text {rd }}$ & $25 / 30(83.33 \%)$ & $26 / 30(86.67 \%)$ & $26 / 30(86.67 \%)$ \\
\hline $4^{\text {th }}$ & $26 / 30(86.67 \%)$ & 28/30 (93.33\%) & $24 / 30(80 \%)$ \\
\hline TOTAL & $206 / 240(85.83 \%)$ & $214 / 240(89.16 \%)$ & $203 / 240(84.5 \%)$ \\
\hline
\end{tabular}




\section{DISCUSSION}

In 2014, the upper cervical spine injury treatment algorithm used in our study based on a literature review and expert opinion was published. The algorithm, divided upper cervical spine injuries into ligamentous injuries (with or without concomitant fractures) and isolated fractures, in an attempt to guide toward the best treatment option ${ }^{9}$. In 2015, preliminary results of a cohort of patients with upper cervical spine injuries, treated according to this rational treatment guide, was published, with 23 patients treated conservatively and 15 surgically managed. During the follow up, the authors reported that there was no neurological worsening and patients with incomplete deficits had some improvement ${ }^{3}$. However, evaluation of the reliability and validity of this system has not been performed since its publication.

In the present series, the majority of the patients were men $(76.7 \%)$, mostly with injuries secondary to motor vehicle accidents (80\%). All patients treated conservatively were neurologically intact $(19 / 19-100 \%)$. However, four in the surgical group (4/11 - 36.36\%) had incomplete deficits. Although neurological deficits are not criteria for instability, they may be associated with more severe injuries that potentially would require surgical treatment.

As noted, a wide range of different classification systems were used by the four spine surgeons, even for similar injury patterns, such as axis fractures. Additionally, we observed that the injury description by itself, or classic eponyms (such as "Jefferson's" or "Hangman's" fractures), were used to describe upper cervical spine injuries, suggesting a heterogeneous classification and potentially difficult comparison of treatment modalities ${ }^{2,11,12,13}$.

The evaluators' treatment options had substantial agreement with the treatment suggested by the application of the algorithm in the majority of the cases (with a substantial kappa value obtained in six of eight comparisons, and moderate and excellent in one comparison each, as shown in Table 5). However, when intra-observer reliability was assessed for the treatment suggested by the application of the algorithm and the actual treatment performed, we obtained an even higher kappa value (a substantial kappa value was obtained in five of eight comparisons and an excellent kappa value in three of eight comparisons, as shown in Table 6). Therefore, the use of a global and more uniform system improves classification reproducibility.
Finally, the inter-observer reliability for the application of the algorithm was substantial (0.63) compared with moderate (0.57) reliability for the evaluators' personal treatment option. Based on this, we infer that the system is more reliable than the surgeon's own opinion about the treatment proposed.

When evaluating safety, we obtained a higher rate of agreement between the application of the algorithm and the treatment actually performed, ranging from $83.3 \%$ to $93.3 \%$, as shown in Table 8 . This suggested that the use of this new system was reliable and safe. Of note, in the 240 evaluations, 20 (58.8\%) of the 34 answers where there was disagreement between the personal treatment option and the algorithm refer to odontoid fracture management. Management of odontoid fractures is controversial, especially for fractures in the dens base, classified according to Anderson and D'Alonzo as type $2^{7,14}$. These injuries had a higher rate of pseudoarthrosis, especially when risk factors for nonunion are present? However, even in the absence of these risk factors, surgical treatment is acceptable. As a consequence, we proposed in our final version of the algorithm that odontoid fractures in the dens base may be treated surgically or conservatively, despite the risk factors for nonunion, based on the surgeon's preference and patient's characteristics (preference, comorbidities, age, etc.), until further evidence for the best treatment option of these injuries is available.

\section{Limitations of the study}

The retrospective application of the algorithm, with limited information, may result in potential bias for a treatment decision. Additionally, it is a guide to treatment, not a descriptive injury system, which may still result in an imprecise description of upper cervical spine injuries. Finally, disability and pain were not specifically addressed, which may alter potential surgical indications. Nonetheless, the patients required no further surgery or intervention for pain management. Due to its practical nature, the algorithm may guide surgical indication, helping to identify the most important factors that lead to conservative or surgical management of these complex injuries.

In conclusion, an acceptable intra- and inter-reliability application of the upper cervical spine injury treatment algorithm is reported in the current study. Additionally, the algorithm was safe to guide treatment of upper cervical spine injuries with respect to neurological morbidity. The management of odontoid fractures in the dens base is still controversial. Further studies evaluating the results of treatment of upper cervical spine injuries are necessary.

\section{References}

1. Anderson LD, D'Alonzo RT. Fractures of the odontoid process of the axis. J Bone Joint Surg Am. 1974;56(8):1663-74. http://doi.org/10.2106/00004623-197456080-00017

2. Effendi B, Roy D, Cornish B, Dussault RG, Laurin CA. Fractures of the ring of the axis. A classification based on the analysis of 131 cases. J Bone Joint Surg Br. 1981;63-B(3):319-27.

3. Joaquim AF, Ghizoni E, Tedeschi H, Yacoub AR, Brodke DS, Vaccaro AR et al. Upper cervical injuries: clinical results using a new treatment algorithm. J Craniovertebr Junction Spine. 2015;6(1):16-20. http://doi.org/10.4103/0974-8237.151585

4. Traynelis VC, Marano GD, Dunker RO, Kaufman HH. Traumatic atlanto-occipital dislocation: case report. J Neurosurg. 1986;65(6):863-70. http://doi.org/10.3171/jns.1986.65.6.0863

5. Menezes AH, Traynelis VC.Anatomy and biomechanics of normal craniovertebral junction (a) and biomechanics of stabilization (b). Childs Nerv Syst. 2008;24(10):1091-100. http://doi.org/10.1007/s00381-008-0606-8 
Sances A, Jr., Myklebust JB, Maiman DJ, Larson SJ, CusickJF, Jodat RW. The biomechanics of spinal injuries. Crit Rev Biomed Eng. 1984;11(1):1-76.

7. Lewis E, Liew S, Dowrick A. Risk factors for non-union in the non-operative management of type II dens fractures. ANZ J Surg. 2011;81(9):604-7. http://doi.org/10.1111/j.1445-2197.2010.05586.x

8. Middendorp JJ, Slooff WB, Nellestein WR, Oner FC. Incidence of and risk factors for complications associated with halo-vest immobilization: a prospective, descriptive cohort study of 239 patients. J Bone Joint Surg Am. 2009;91(1):71-9. http://doi.org/10.2106/JBJS.G.01347

9. Joaquim AF, Ghizoni E, Tedeschi H, Lawrence B, Brodke DS, Vaccaro AR et al. Upper cervical injuries - a rational approach to guide surgical management. J Spinal Cord Med. 2014;37(2):139-51. http://doi.org/10.1179/2045772313Y.0000000158

10. Anderson PA, Montesano PX. Morphology and treatment of occipital condyle fractures. Spine. 1988;13(7):731-6. http://doi.org/10.1097/00007632-198807000-00004

11. Levine AM, Edwards CC. The management of traumatic spondylolisthesis of the axis. J Bone Joint Surg Am. 1985;67(2):217-26. http://doi.org/10.2106/00004623-198567020-00007

12. Hays MB, Alker GJ, Jr. Fractures of the atlas vertebra. The two-part burst fracture of Jefferson. Spine. 1988;13(6):601-3. http://doi.org/10.1097/00007632-198813060-00001
13. Levine AM, Edwards CC. Fractures of the atlas. J Bone Joint Surg Am. 1991;73(5):680-91.

14. Grauer JN, Shafi B, Hilibrand AS, Harrop JS, Kwon BK, Beiner JM et al. Proposal of a modified, treatment-oriented classification of odontoid fractures. Spine J. 2005;5(2):123-9. http://doi.org/ 0.1016/j.spinee.2004.09.014

15. Landis JR, Koch GG. An application of hierarchical kappatype statistics in the assessment of majority agreement among multiple observers. Biometrics. 1977;33(2):363-74. http://doi.org/10.2307/2529786

16. Benzel EC, Hart BL, Ball PA, Baldwin NG, Orrison WW, Espinosa M. Fractures of the C-2 vertebral body. J Neurosurg. 1994;81(2):206-12. http://doi.org/10.3171/jns.1994.81.2.0206

17. Fujimura Y, Nishi Y, Kobayashi K. Classification and treatment of axis body fractures. J Orthop Trauma. 1996;10(8):536-40. http://doi.org/10.1097/00005131-199611000-00005

18. Fielding JW, Hawkins RJ, Ratzan SA. Spine fusion for atlantoaxial instability. The J Bone Joint Surg Am. 1976;58(3):400-7. http://doi.org/10.2106/00004623-197658030-00020

19. Tuli S, Tator CH, Fehlings MG, Mackay M. Occipital condyle fractures. Neurosurgery. 1997;41(2):368-376. http://doi.org/10.1097/00006123-199708000-00006 